\title{
A Review of Interlanguage Pragmatics Studies
}

\author{
Yingying Peng \\ School of Foreign Languages \\ Central China Normal University \\ Wuhan, China 430079
}

\author{
Xiaofang Gao \\ School of Foreign Languages \\ Central China Normal University \\ Wuhan, China 430079
}

\begin{abstract}
Interlanguage Pragmatics (ILP) was established in the late 1970s. Since its emergence many researchers devoted themselves to its theoretical and empirical studies, and have made great achievements. The purpose of this article is to review its research domains and data collection methods in ILP, and discuss its prospect in the future.
\end{abstract}

\section{Keywords—interlanguage; pragmatics; review}

\section{INTRODUCTION}

Interlanguage (IL), first used by Selinker in his paper "Language Transfer" (1969), is the term used to describe an interim language system developed by second language learners which is different from both their first language (L1) and second language (L2). Since the late 1970s, researches of L2 began to focus on pragmatics, thus Interlanguage Pragmatics, an interdisciplinary study which is based on second language acquisition (SLA) and pragmatics, was established. We would like to focus our review on ILP research development and its prospect in the future.

\section{DOMAINS OF ILP}

Kasper and Dahl (1991) defined ILP as "the study of non-native speakers' acquisition, comprehension and production of pragmatics". In this part we will give a brief review on the domains of ILP in chronological order.

\section{A. Early Stage}

Within the first decade of its development, researches of ILP mainly focused on the following aspects:

The first aspect is on comparative studies of pragmatic use. To be more specific, researches focused on the differences between native speakers (NS) and non-native speakers (NNS) based on cross-cultural differences (e.g., Eisenstein \& Bodman, 1986; House \& Kasper, 1987; Olshtain \& Weinbach, 1987; Tanaka, 1988; Takahashi \& Beebe, 1989). Blum-Kulka (1982) compared request performance by NS and NNS in Hebrew. She concluded that NNS tended to use less direct strategies than NS when making a request, but they used the same range of strategies on the whole. Banerjee and Carrel (1988) examined how NNS of English performed speech act of suggestion. Compared to NS of English, NNS were less likely to make suggestions. Blum-Kulka and Olshtain (1986) studied the speech act of request by NS and NNS in Hebrew from the perspective of utterances length. They found that NNS tend to use more words to make a request than NS.

One of the reasons that NS and NNS performed differently is attributed to the influence of learners' native language and culture, thus another aspect of ILP research is on pragmatic transfer. Researchers investigated pragmalinguistic transfer and sociopragmatic transfer, and their relationship with pragmatic failure and pragmatic competence (e.g., Cohen \& Olshtain, 1981; Gass \& Selinker, 1983; Thomas, 1983). Trosborg (1987) studied apology realizations by Danish learners of English in L1 and L2. She noticed that there was transfer from the native language to the target language, but there was not a clear case of negative L1 transfer in her study of NNS' apology. Also Fraser (1978), Rintell (1981), and Blum-Kulka (1983) provided evidence of pragmatic transfer in their researches.

The third aspect is on learners' pragmatic comprehension of speech acts in target language, but from a nondevelopmental perspective, mainly on learners' ability to understand the illocutionary meaning of an utterance and variables that affect ILP comprehension. Carrell (1979) studied learners' comprehension of indirect answers, and concluded that NNS had difficulty in understanding indirect answers which are culture-specific. In her another study, Carrell (1981a) investigated NNS' comprehension of request. It was proved that the linguistic properties of the request speech act influenced learners' comprehension, and positive requests were more easily understood than negative ones. As for variables affecting learners' ability of understanding the target language, researchers studied factors of grammar (Walters, 1980), time of studying L2 (Schmidt, 1983), social affective factors (Schumann, 1978), etc.

The last aspect of ILP study in the early stage is about learners' perception of politeness in speech act strategies, which can be described as "metapragmatic judgment studies, as the issue in focus is not on-line perception of politeness in context but relatively permanent states of pragmatic knowledge" (Kasper \& Dahl, 1991). Walters (1979) looked at the perception of politeness in request. He concluded that NS' and NNS' perception of politeness were basically the same on the whole. In their study, Carrell and Konneker (1981) argued that NNS of English distinguished more levels of politeness in request than NS do. Olshtain and BlumKulka (1985) asked NNS to rate the politeness in request and apology described in a questionnaire. They found that the 
longer NNS stay in the target community, the better they did in politeness judgment.

\section{B. Stage of Development}

Since the 1990s, ILP takes shape, and has widened its scope mainly on the following aspects:

Compared with earlier studies on learners' comprehension of speech acts from a non-developmental perspective, ILP researchers begun to focus on the developmental aspects of ILP, such as comparing learners' comprehension accuracy based on their different language proficiency levels (e.g. Bardovi-Harlig \&Hartford, 1993a; Kasper \& Schmidt, 1996b; Rose \& Kasper, 2001; Taguchi, 2005;). According to Kasper and Schmidt (1996a) learners' language proficiency have little influence on their use of speech act strategies on the whole. By investigating NNS' pragmatic performance in request, Cook and Liddicoat (2002) showed us how proficiency influenced NNS' language processing. Generally speaking, high-proficiency learners do better than low-proficiency learners in target language comprehension and production.

An increasing number of studies talked about NNS' pragmatic competence. In these studies, researchers investigated NNS' production of linguistic actions, summarized NNS' pragmatic features (e.g. Bergman \& Kasper, 1993; Eisenstein \& Bodman, 1993; Farnia, 2009; Wijayanto, Laila, Prasetyarini \& Susiati, 2013; Usó-Juan \& Martínez-Flor, 2015) and discussed the relationship between grammar and pragmatic competence (e.g. Schachter, 1990; Kasper \& Rose, 2002; Bardovi-Harlig, 2003), or they collected cross-sectional or longitudinal data to observe how learners' pragmatic competence is developed (e.g. Barron, 2003; Schauer, 2006; Chang,2010). Rose (2000, 2009) examined learners' acquisition of pragmatic competence, and found that in the early stages of pragmatic development there were obvious pragmalinguistic development, but little sociopragmatic development. Sabate and Curell (2007) collected data from 78 participants at three different language proficiency levels to study the development of expressing apology.

What's more, there are a large amount of researches investigated variables affecting L2 learners' pragmatic development, such as age, social knowledge, cognitive maturity, linguistic proficiency, etc. Tajeddin and ZandMoghadam (2012) investigated the impact of motivation in the acquisition of ILP competence. Korshidi (2013) described the influence of "studying abroad context on L2 learners' pragmatic development" by analyzing how NNSs make request and apology.

Another strand of pragmatic competence concerned pedagogical issues, trying to indicate how pragmatic competence can be developed. The majority of these studies analyzed the effects of pragmatic knowledge instruction on learners' pragmatic competence. For example, House (1996) discussed whether instructors should explicitly teach pragmatic knowledge to high-proficiency learners. It is argued that explicit instruction involving pragmatics is indispensable (Bardovi-Harlig, 2001; Eslami, 2010). They claimed the superiority of explicit instruction over implicit one in developing learners' pragmatic proficiency (House, 1996; Takahashi, 2001; Kasper \& Roever, 2005; Abrams, 2014). Takimoto (2008) looked into how input-based instruction can be used as enhancement activities in L2 teaching to improve learners' pragmatic competence. There are also studies on instructional environments in L2 (e.g. Yang \& Zapata-Rivera, 2010; Samar \& Ahmadi, 2014). Ohta (2005) tried to link Vygotsky's zone of proximal development to ILP teaching and learning. Linares and Pastrana observed learners' interaction in the classroom to assess the frequency of communicative functions (see Ifantidou \& Matsui, 2013).

One of the emerging questions within ILP is how learners' pragmatic competence can be properly measured: how to assess pragmatic competence? What instruments can be used to measure? Whether speech acts can reflect learners' pragmatic competence completely? (Ross \& Kasper, 2013).

\section{INSTRUMENTS}

In this part we will give a brief review on the instruments used in ILP studies since its emergence. The focus will be on data collection methods rather than ways of analysis. Generally speaking, there were five instruments researchers often use in ILP studies since the 1980s, namely, rating tasks, questionnaires, role play, interviews, and observation of authentic discourse.

\section{A. Rating Tasks}

In the first decade, rating tasks (including paired comparing, card sorting, and rating scales) were often used to examine participants' perception of politeness in speech acts. For example, Walters (1979) studied the perception of politeness in request by asking participants to do paired comparing. To be more specific, participants were asked to consider the relative politeness value of two utterances whose locutionary meaning are similar to each other. Another kind of rating tasks researchers often use was card sorting tasks. Participants were presented with cards describing different contexts and speech act strategies, and were asked to classify these strategies or choose one based on a certain criterion (e.g. Carrell \& Konneker, 1981; Tanaka \& Kawade, 1982). What's more, rating scales were often adopted to rate a certain speech act strategy or an utterance for its appropriateness or politeness on a point scale (e.g. Olshtain \& Blum-Kulka, 1985; Kerekes; 1992; Maeshiba et al., 1996; Hinkel, 1996; Takimoto, 2009).

However, in present studies researchers seldom use paired comparing tasks or card sorting tasks. As for rating scales, it is often used for participants doing Discourse selfassessment tasks (DSAT), Role-play self-assessment (RPSA) or self-assessment in retrospective experiments. DSAT and RPSA are both designed to judge participants' ability to perform appropriately in a situation. DSAT describes situations in a written form (Hudson, Detmwe \& Brown, 1995), while RPSA presents them through video. After reading description of situations or watching a video role- 
play, participants are asked to rate a score to evaluate their "ability to speak appropriately for a speech act" (Gao, 2014). When it is used in retrospective studies, participants are asked to rate the appropriateness or other features of their previous performance.

\section{B. Questionnaires}

Questionnaires used in ILP studies are mainly consists of two kinds: multiple choice questionnaires and Written Discourse Completion Task (WDCT). The former first gives a brief description of a situation either in a written form (Carrell, 1979; Cook, 2002; Bataineh \& Bataineh, 2008), or tape-recorded (Carrell, 1981b), or providing pictures together with written description (Tanaka \& Kawade, 1982), and then provide several choices for participants to choose. Nowadays, the multiple choice questionnaire may also be designed to contain an empty slot, together with choices for participants to write their responses if none of the provided choices suits them.

As for WDCT, a written questionnaire, it was used most in ILP (e.g. Blum-Kulka, 1982; House \& Kasper, 1987; Faerch \& Kasper, 1989; Svanes,1992; Sasaki, 1997; Ohta, 2005; Lee, 2010; Khorshidi \& Nimchahi, 2013; Yarahmadi \& Fathi, 2015). Usually the discourse completion tasks questionnaire includes a number of brief situational descriptions (such as setting, participant role, status, age, etc.), followed by a short dialogue with an empty slot for the speech act under study. Participants are asked to write a response which they consider most appropriate. Compared with multiple choice questionnaire, WDCT questionnaire provides researchers more authentic data, for participants cannot choose an answer randomly, or will not get any hint from listed answers.

\section{Role-play}

Role-play includes closed role-play and open role-play. When participants doing a closed role-play, they are given a description of a situation and asked to write down or say aloud what they would say in that situation (e.g. Walters, 1980; Andersen, 1989; Sasaki, 1997; Rose, 2009; Wijayanto, Laila, Prasetyarini \& Susiati, 2013).

Open role-plays, also called discourse role-play task (DRPT), provide participants with a role card, and ask them to play a conversation with an interlocutor based on a given situation (e.g. Scarcella, 1979; Trosborg, 1987; Houck \& Gass, 1996; Félix-Brasdefer, 2003; Takimoto, 2009; Baba, 2010). Compared with closed role-play, it allows researchers to analyze a speech act behaviour in its full discourse context.

\section{Interviews}

Interviews are often used as a retrospective experiment. They may be used after a discourse completion questionnaire for participants judging their performance (Eisenstein \& Bodman, 1986), expressing their opinions about the experiments (Shively, 2011), and doing self-reflection (Félix-Brasdefer, 2003), etc.

\section{E. Observation of Authentic Discourse}

In the late 1980s, researchers begun to use authentic data in ILP studies. For example, Wolfson (1989b) observed and recorded naturally occurring speech in everyday interactions to study NNS' expression of compliment. Bardovi-Harlig and Hartford (1990, 1993a) audio-taped 32 academic advising sessions to compare NNS' speech acts of suggestions and rejections to that of NS. The data BardoviHarlig and Hartford used in these two researches belong to institutional talk. Since then ILP researches revealed a desire to explore institutional talk in ILP researches. As institutional talk occurs in the course of carrying out an institution's business, it is comparable, predictable, and relatively easy to collect data compared with other sources of authentic data. Thus, an increasing number of studies used institutional talk as data in their research. For example, Tyler (1995) examined miscommunication by recording tutoring sessions. Churchill (1999) studied requests in academic setting. Kerekes (2001) observed and recorded employment interview to analyze NNS' linguistic behaviours and conversational strategies. Economidou-Kogetsidis (2011) studied pragmatic failure by analyzing NNS' emails.

\section{CONCLUSION}

An increasing number of linguists have devoted themselves to the study of ILP, combining second or foreign language acquisition with pragmatics in order to find more effective ways of teaching and learning second or foreign language. After nearly forty years of development, interlanguage pragmatics has made great achievements. Firstly, the research content of ILP was expanded. To be more specific, in early researches, researchers mainly focused on a few face threatening speech acts, such as request and complaint, but the current studies deal with different kinds of speech acts. In other words, they not only investigate politeness strategies that learners use in request or complaint, they also observe learners' performance of promising, greeting, congratulation, and so on. Secondly, studies in nowadays do not simply summarize learners' interlanguage speech act performance and pragmatic features, they pay attention to learners' ILP competence development, namely, their acquisition of pragmatic speaking norms of a target language speech community. Thirdly, participants' background in ILP studies was enriched. In previous studies, second language or foreign language learners were the only participants in ILP studies, but now we have researches that take the second generation of immigrants as research participants, for their language system was not only influenced by the target language norms, but also affected by the native language norms from their parents.

As for the instruments in ILP studies, they are workable and manageable. Researchers used various data collection methods to gather the most appropriate language data in their researches. Those instruments have made ILP researches easy to operate.

We can tell from what we have summarized that previous studies have provided us sufficient instances of tightly controlled data to study language learners' conversational 
and interpersonal phenomena which may help us to understand pragmatic features and development of ILP. However, we have to consider the validity of these highly controlled data, particularly their adequacy to reveal learners' real level of ILP competence. For example, what WDCT and closed role-plays provided us are non-interactive data, and what multiple-choices questionnaire gave us are answers provided by researchers. It is necessary to consider the extent that those controlled data can show us about participants' real performance in authentic situations. Clearly there is a great need for authentic data, thus institutional talk is a relatively appropriate and a rich source of data for ILP studies. For example, second language teaching classes, commercial activities with foreigners, foreign language publications, and affairs in foreign-related department are all sources of institutional talk. What's more, our access to other languages may be limited, so the target language we have studied mainly focused on English. We should pay more attention to other languages, such as Chinese, German, Spanish, and so on. The expansion of the study scope of the target language may shed light on the application scope of theories and research methods in ILP studies. In other words, there is a need to analyze whether the theories and methods we concluded from previous ILP studies can help us understand IL pragmatic features and development of NNS of other languages except English.

\section{REFERENCES}

[1] L. Selinker, "Language transfer," General Linguistics, vol. 2, 1969, pp. 67-92.

[2] M. Eisenstein, and J. Bodman, "II very appreciate': Expressions of gratitude by native and non-native speakers of American English," Applied Linguistics, vol. 7, 1986, pp. 64-81.

[3] J. House, and G. Kasper, "Interlanguage pragmatics: Requesting in a foreign language," in Perspectives on Language in Performance: Festschrift for Werner Huellen, L. Wolfgang and S. Rainer, Eds. Tuebingen: Narr, 1987, pp. 1250-1288.

[4] E. Olshtain, and L. Weinbach, "Complaints: A study of speech act behavior among native and non-native speakers of Hebrew," in The Pragmatic Perspective, V. Jef and B. Marcella, Eds. Amsterdam: Benjamins, 1987, pp. 195-208.

[5] N. Tanaka, "Politeness: some problems for Japanese speakers of English," JALT Journal, vol. 9, 1988, pp. 81-102.

[6] T. Takahashi and L. M. Beebe, "Sociolinguistic variation in facethreatening speech acts: Chastisement and disagreement," in The Dynamic Interlanguage: Empirical Studies in Second Language Variation, M. R. Eisenstein, Ed. New York: Plenum Press, 1989.

[7] S. Blum-Kulka, "Learning how to say what you mean in a second language: A study of speech act performance of learners of Hebrew as a second language," Applied Linguistics, vol. 3, 1982, pp. 29-59.

[8] J. Banerjee, and P. L. Carrell, "Tuck in your shirt, you squid: Suggestions in ESL," Language Learning, vol. 38, 1988, pp. 313-347.

[9] S. Blum-Kulka, and E. Olshtain, "Too many words: Length of utterance and pragmatic failure," Journal of Pragmatics, vol. 8, 1986, pp. $47-61$.

[10] A. D. Cohen, and E. Olshtain, "Developing a measure of sociocultural competence: The case of apology," Language Learning, vol. 31, 1981, pp. 113-114.

[11] S. Gass, and L. Selinker, Language Transfer and Language Learning. Rowley, MA: Newbury House, 1983, pp.232-249.

[12] J. Thomas, "Cross-cultural pragmatic failure," Applied Linguistics, vol. 4, 1983, pp. 91-112.
[13] A. Trosborg, "Apology strategies in native/ non-natives," Journal of Pragmatics, vol. 11, 1987, pp. 147-167

[14] B. Fraser, "Acquiring social competence in a second language," RELC Journal, vol. 9, 1978, pp. 1-26.

[15] E. Rintell, "Sociolinguistic variation and pragmatic ability: A look at learners," Internatinal Journal of the Sociology of Language, vol. 27, 1981, pp. 11-34.

[16] S. Blum-Kulka, "Interpreting and performing speech acts in a second language: A cross-cultural study of Hebrew and English," in Sociolinguistics and Second Language Acquisition, N. Wolfson and E. Judd, Eds. Rowley, MA: Newbury House, 1983.

[17] P. L. Carrell, "Indirect speech actsin ESL: Indirect answers," in On TESOL, A. Y. Carlos, K. Perkins and J. Schachter, Eds. Washingron, D.C.: TESOL, 1979, pp. 297-307.

[18] P. L. Carrell, "Children's understanding of indirect requests: comparing child and adult comprehension," Journal of Child Lnguage, vol. 8, 1981a, pp. 329-345.

[19] J. Walters, "Grammar, meaning and sociocultural appropriateness in second language acquisition," Canadian Journal of Psychology, vol. 34, 1980, pp. 337-345.

[20] R. Schmidt, "Interaction, acculturation and the acquisition of communicative competence," in Sociolinguistics and Second Language Acquisition, N. Wolfson and E. Judd, Eds. Rowley, MA: Newbury House, 1983, pp. 137-174.

[21] J. H. Schumann, "The acculturation model for second language acquisition," in Second Language Acquisition and Foreign Language Teaching, R. C. Gingras, Ed. Virginia: Centre for Applied Linguistics, 1978, pp. 27-50.

[22] G. Kasper and M. Dahl, "Research methods in interlaguage pragmatics," Studies in Second Language Acquisition, vol. 13, 1991, pp. $215-247$.

[23] J. Walters, "The perception of deference in English and Spanish," in On TESOL, A. Y. Carlos, K. Perkins and J. Schachter, Eds. Washingron, D.C.: TESOL, 1979, pp. 288-296.

[24] P. L. Carrell and B. H. Konneker, "Politeness: Comparing native and nonnative judgments," Language Learning, vol. 31, 1981, pp. 17-31.

[25] E. Olshtain and S. Blum-Kulka, "Degree of approximation Nonnative reactions to native speech act behavior," in Input in Second Language Acquisition, S. M. Gass and C. Madden, Eds. Rowley, Mass.: Newbury House, 1985, pp. 303-325.

[26] K. Bardovi-Harlig and B. S. Hatford, "Learning the rules of academic talk: A longitudinal study of pragmatic development," Studies in Second Language Acquisition, vol. 15, 1993a, pp. 279-304.

[27] G. Kasper and R. Schmidt, "Developemtal issues in interlanguage pragmatics," Studies in Second Language Acquisition, vol. 18 (2), 1996b, pp. 149-169.

[28] K. R. Rose and G. Kasper, "Pragmatics in languge teaching," in Pragmatics in Languge Teaching, K. R. Rose and G. Kasper, Eds. Cambridge: Cambridge University Press, 2001.

[29] N. Taguchi, "Comprehending implied meaning in English as a foreign language," Modern Language Journal, vol. 89, 2005, pp. 543562 .

[30] G. Kasper and R. Schmidt, "Developemtal issues in interlanguage pragmatics," Studies in Second Language Acquisition, vol. 18 (1), 1996a, pp. 149-169.

[31] M. Cook and A. J. Liddicoat, "The development of comprehension in interlanguage pragmatics: The case of request strategies in English," Australian Review of Applied Linguistics, vol. 25, 2002, pp. 19-39.

[32] M. Bergman and G. Kasper, "Perception and performance in native and nonnative apology," in Interlanguage Pragmatics, G. Kasper and S. Blum-Kulka, Eds. Oxford: Oxford University Press, 1993, pp. 82107.

[33] M. Eisenstein and J. Bodman, "Expressing gratitude in American English," in Interlanguage Pragmatics, G. Kasper and S. Blum-Kulka, Eds. Oxford: Oxford University Press, 1993, pp. 64-81.

[34] M. Farnia, "An interlanguage pragmaic study of expressions of gratitude by Iranian EFL learners: A pilot study," Malaysian Journal of ELT Research, vol. 5, 2009, pp. 108-140. 
[35] A. Wijayanto, M. Laila, A. Prasetyarini and S. Susiati, "Politeness in interlanguage pragmatics of complaints by Indonesian learners of English,” English Language Teaching, vol. 6, 2013,pp. 188-201.

[36] E. Usó-Juan and A. Martínez-Flor, "Assessing EFL learners' performance of the conventional expressions of complaining and apologising," Social and Behavioral Science, vol. 173, 2015, pp. 5360 .

[37] J. Schachter, "Communicative competence revisited," in The Development of Second Language Proficiency, B. Harley, P. Alien, J. Cummins and M. Swain, Eds. New York: Cambridge University Press, 1990, pp. 303-325.

[38] G. Kasper and K. R. Rose, Pragmatic Development in a Second Language. Oxford: Blackwell, 2002.

[39] K. Bardovi-Harlig, "Under the role of grammar in the acquisition of L2 pragmatics," in Pragmatic Competence and Foreign Language Teaching, A. Martínez-Flor, E. Usó-Juan and A. Fernández-Guerra, Eds. Castell de la Plana: Spain Publications de la Universitat Jaume I, 2003, pp. 25-44.

[40] A. Barron, Acquisition in Interlanguage Pragmatics: Learning How to Do Things with Words in a Study Abroad Context. Amsterdam: John Benjamins Publishing Company, 2003.

[41] G. Schauer, "Pragmatic awareness in ESL and EFL contexts: contrast and development," Language Learning, vol. 56, 2006, pp. 269-317.

[42] Y. F. Chang, "I no say you say is boring: the development of pragmatic competence in L2 apology," Language Science, vol. 32, 2010, pp. 408-424.

[43] K. R. Rose, "An exploratory cross-sectional study of interlanguage pragmatic development," SSLA, vol. 22, 2000, pp. 27-67.

[44] K. R. Rose, "Interlanguage pragmatic development in Hong Kong, phase 2," Journal of Pragmatics, vol. 4, 2009, pp. 2345-2364.

[45] D. M. Sabate and G. H. Curell, "From 'sorry very much' to 'I'm ever so sorry': Acquisitional aptterns in L2 apologies by Catalan learners of English," Intercultural Pragmatics, vol. 4, 2007, pp. 287-315.

[46] Z. Tajeddin and A. Zand-Moghadam, "Interlanguage pragmatic motivation: Its construct and impact on speech act production," RELC Journal, vol. 43, 2012, pp. 353-372.

[47] H. R. Khorshidi, "Study abroad and interlanguage pragmatic development in request and apology speech acts among Iranian learners," English Language Teaching, vol. 6, 2013, pp. 62-70

[48] J. House, "Developing pragmatic fluency in English as a foreign language: Routines and metapragmatic awareness," Studies in Second Language Acquisition, vol. 24, 1996, pp. 225-252.

[49] K. Bardovi-Harlig, "Empirical evidence of the need for instruction in pragmatics," in Pragmatics in Language Teaching, K. R. Rose and G. Kasper, Eds. New York: Cambridge University Press, 2001, pp. 1332.

[50] Z. R. Eslami, "Refusals: How to develop appropriate refusal strategies," in Speech Act Performance: Theoretical, Empirical and Methodological Issues, A. Martínez-Flor and E. Usó-Juan, Eds. John Benjamins Publicating Company, 2010, pp. 217-236.

[51] S. Takahashi, "The role of input enhancement in developing pragmatic competence," in Pragmatics in Language Teaching, K. R. Rose and G. Kasper, Eds. New York: Cambridge University Press, 2001, pp. 171-199.

[52] G. Kasper and C. Roever, "Pragmatics in second language learning," in Handbook of Research in Second Language Teaching and Learning, E. Hinkel, Ed. Mahwah, NJ: Lawrence Erlbaum Associates, 2005, pp. 317-334.

[53] Z. I. Abrams, "Using film to proide a context for teaching L2 pragmatics," System, vol. 46, 2014, pp. 55-64.

[54] M. Takimoto, "The effect of inout-based tasks on the development of learners' pragmatic proficiency," Applied Linguistics Advance Access, vol. 28, 2008, pp. 1-25.

[55] H. C. Yang and D. Zapata-Rivera, "Interlanguage pragmatics with a pedagogical agent: The request game," Computer Assisted Language Learning, vol. 23, 2010, pp. 395-412.
[56] R. G. Samar and A. H. Ahmadi, "Teaching requestive downgraders in L2: How effective are written vs. oral output-based tasks," Social and Behavioral Science, vol. 98, 2014, pp. 532-541.

[57] A. S. Ohta, "Interlanguage pragmatics in the zone of proximal development," System, vol. 33, 2005, pp. 503-517.

[58] E. Ifantidou and T. Matsui, "Pragmatic development in L1, L2, L3 Its biological and cultural foundations," Journal of Pragmatics, vol 59, 2013, pp. 1-4.

[59] S. Rose and G. Kasper, Assessing Second Language Pragmatics. New York: Palgrave Macmillan, 2013.

[60] S. Tanaka and S. Kawade, "Politeness strategies and second language acquisition," Studies in Second Language Acquisition, vol. 5, 1982 pp. 18-33.

[61] J. Kerekes, Development in Nonnative Speakers' Use and Perception of Assertiveness and Supportiveness in Mixed-sex Conversations. Honolulu, HI: University of Hawai'i at Manoa, Department of English as a Second Language, 1992

[62] N. Maeshiba, N. Yoshinaga, G. Kasper and S. Ross, "Transfer and proficiency in interlanguage apologizing," in Speech Acts Across Cultures, S. M. Gass and J. Neu, Eds. Berlin: Mouton de Gruyter, 1996, pp. 155-187.

[63] E. Hinkel, "When in Rome: Evaluations of L2 pragmalinguistic behaviors," Journal of Pragmatics, vol. 26, 1996, pp. 51-70.

[64] M. Takimoto, "Exploring the effects of input-based treatment and test on the development of learners' pragmatic proficiency," Journal of Pragmatics, vol. 41, 2009, pp. 1029-1046.

[65] T. Hudson, E. Detmer and J.D. Brown, Developing Prototypic Measures of Cross-Cultural Pragmatics (Technical Report \#7). Honolulu: University of Hawaii, Second Language Teaching \& Curriculum Center, 1995

[66] V. J. Cook, "Background to the L2 user," in Portraits of the L2 User, V. J. Cook, Ed. Clevedon: Multilingual Matters, 2002, pp. 1-28.

[67] R. F. Bataineh and R. F. Bataineh, "A cross-culture comparison of apologies by naïve speaker of American English and Jordanian Arabic," Journal of Pragmatic, vol. 40, 2008, pp. 792-821.

[68] S. Tanaka and S. Kawade, "Politeness strategies and second language acquisition," Studies in Second Language Acquisition, vol. 5, 1982, pp. $18-33$.

[69] C. Faerch and G. Kasper, "Internal and external modification in interlanguage request realization," in Cross-Cultural Pragmatics, S. Blum-Kulka, J. House and G. Kasper, Eds. Norwood,N.J.: Ablex, 1989, pp. 221-247.

[70] B. Svanes, "Development of realization patterns of the speech act 'asking someone to do something' by foreign students during three years in Norway," Norwegian Linguistics Journal, vol. 1, 1992, pp. $1-50$.

[71] C. Lee, "An exploratory study of the interlanguage pragmatic comprehension of young learners of English," Pragmatics, vol. 20, 2010, pp. 343-373.

[72] M. Sasaki, "Topic continuity in Japanese English interlanguage," IRAL, vol. 35, 1997, pp. 1-22.

[73] H. R. Khorshidi and A. B. Nimchahi, "Motivation and interlanguage pragmatics in Iranian English Learners," English Language Teaching, vol. 6, 2013, pp. 86-96.

[74] A. Yarahmadi and S. Fathi, "A cross cultural study on Iranian EFL students' pragmatic transfer," Social and Behavioral Science, vol. 192 2015, pp. 498-505

[75] E. Andersen, "Speaking with style: The sociolinguistic skills of children," London: Routledge, 1989.

[76] A. Wijayanto, M. Laila, A. Prasetyrini and S. Susiati, "Politeness in interlanguage pragmatics of complaints by Idonesian learners of English," English Language Teaching, vol. 6, 2013, pp. 188-201.

[77] R. Scarcella, "On speaking politely in a second language," in On TESOL, A. Y. Carlos, K. Perkins and J. Schachter, Eds. Washington, D.C.: TESOL, 2001, pp. 275-287. 
[78] N. Houck and S. M. Gass, "Non-native refusals: A methodological perspective," in Speech Acts Across Cultures, S. M. Gass and J. Neu, Eds. New York: Mouton de Gruyter, 1996, pp. 45-64.

[79] J. C. Félix-Brasdefer, "Declining an invitation: A cross-cultural study of pragmatic strategies in American English and Latin American English and Latin American Spanish," Multilingua, vol. 22, 2003, pp. 225-255.

[80] J. Baba, "Interlanguage pragmatics study of indirect complaint," Sino-US English Teaching, vol. 7, 2010, pp. 23-32bodma.

[81] R. L. Shively, "L2 pragmatic development in study abroad: A longitudinal study of Spanish service encounters," Journal of Pragmatics, vol. 43, 2011, pp. 18-35.

[82] N. Wolfson, "The social dynamics of native and nonnative variation in complimenting behavior," in The Dynamic Interlanguage, M. Eisenstein, Ed. New York: Plenum, 1989b, pp. 219-236.

[83] K. Bardovi-Harlig and B. S. Hartford, "Congruence in native and nonnative conversations: Status balance in the academic advising session," Language Learning, vol. 40, 1990, pp. 467-501.

[84] A. Tyler, "The coconstruction of cross0cultural miscommunication: Conflicts in perception, negotiation and enactment of participant role and status," Studies in Second Language Acquisition, vol. 17, 1995, pp. $129-152$.

[85] E. F. Churchill, "Pragmatic development in L2 request strategies by lower level learners," Paper presented at the Second Language Research Forum, Minneapolis, MN, 1999.

[86] J. Kerekes, "The co-construction of a successful gatekeeping encounter: Strategies of linguistically diverse speakers," Doctoral thesis, submitted to the School of Education, Stanford University, Stanford, California, 2001.

[87] M. Economidou-Kogetsidis, "Please answer me as soon as possible: Pragmatic failure in non-native speakers' e-mail requests to faculty," Journal of Pragmatics, vol. 43, 2011, pp. 3139-3215.

[88] X. F. Gao, "Assessing instruments and their application in empirical studies of interlanguage pragmatics in China", Proceedings of the Third Northeast Asia International Symposium on Language, Literature and Translation. Georgia: the American Scholars Press, U.S.A, 2014, 456-462. 